\title{
Upaya Gereja Dalam Mentransformasi Kemiskinan
}

Gereja adalah sebuah lembaga yang didalamnya selalu terdapat stratifikasi sosial, dimana adanya sebuah perbedaan antara kedudukan yang lebih tinggi dan lebih rendah. Lapisan rendah atau yang sering disebut masyarakat miskin memiliki ciri khas tersendiri dan cenderung menarik diri dari komunitas lapisan tinggi atau sering disebut masyarakat kaya. Masalah kemiskinan terjadi tidak hanya dalam pedesaan tetapi juga perkotaan yang dapat dilihat dari minimnya pendapatan keluarga, rumah tanpa fasilitas yang memadai juga kurangnya pendidikan.

Gereja hadir di tengah masyarakat untuk menjadi terang dam garam. Kontribusi gereja diharapkan tidak hanya sekedar untuk membantu masyarakat miskin, tetapi juga berdampak bagi transformasi kehidupan yang lebih layak. Dalam hal ini gereja memiliki misi sosial, misi sosial adalah upaya yang dilakukan gereja untuk mengatasi masalah yang terjadi dalam sebuah masyarakat (Larosa, 2001). Gereja diharapkan berfungsi tidak hanya sampai pada permukaan, tetapi berani mengambil langkah nyata untuk bertindak. Tidak hanya persoalan kemiskinan, tetapi juga penanaman sikap keadilan yang memberi ruang kepada masyarakat miskin untuk ambil bagian dalam kehidupan bergereja.

Aksi sosial yang sering dilakukan oleh gereja seperti membagi sembako kepada jemaat miskin, mengadakan pasar murah, memberi uang dsb adalah wujud gereja membantu perekonomian jemaat. Untuk sebuah transformasi, gereja tidak bisa berhenti di tahap sekedar memberi bantuan, tetapi perlu dilakukan upaya agar jemaat tidak hanya terbantu tetapi juga mengalami pertumbuhan dalam kehidupannya. Salah satu upaya yang dapat dilakukan gereja adalah pemberdayaan jemaat.

Pemberdayaan jemaat sebagai wujud jemaat dalam mengekspresikan ajaran Tuhan dalam kehidupan sehari-hari serta mendorong jemaat dalam memperjuangkan iman dalam realitas sosial yang sedang terjadi. ${ }^{1}$ Dengan adanya kerjasama antara gereja dan masyarakat akan membawa dampak yang signifikan. Gereja perlu untuk memiliki kepedulian sosial di tengah masyarakat untuk merefleksikan firman Tuhan sehingga masyarakat miskin "tidak gagal" dalam melihat Yesus.

${ }^{1}$ Fibry Jati Nugroho, Gereja dan Kemiskinan: Diskursus Peran Gereja di Tengah Kemiskinan volume 3 , nomor 1, Januari 2019, diakses pada tanggal 3 Februari 2020 pukul 00:37. 